\title{
ANALISIS KEJAHATAN BERBAHASA DALAM BERSOSIAL MEDIA (LINGUISTIK FORENSIK)
}

\author{
Herwin, Mahmudah, Saleh \\ Program Pascasarjana Magister Pendidikan Bahasa (Bahasa Indonesia), Universitas \\ Negeri Makassar, Makassar, Sulawesi Selatan, Indonesia \\ herwinachmad2@gmail.com
}

\begin{abstract}
ABSTRAK: Penelitian ini merupakan penelitian deskriptif kualitatif yang bertujuan untuk mendeskripsikan kejahatan berbahasa berdampak hukum pada tindak tutur ilokusi ekspresif bentuk penghinaan, fitnah, dan makian. Ditemukan dalam penelitian berupa kejahatan berbahasa berdampak hukum pada tindak tutur ilokusi ekspresif bentuk penghinaan, fitnah, dan makian. Pertama, Bentukbentuk ilokusi penghinaan yang dilakukan oleh pengguna media sosial pada masa pra dan pasca pemilihan Walikota Makassar 2020 ditemukan bebarapa bentuk ilokusi tindak tutur ekspresif penghinaan yaitu omong kosong, omong doang, pakai otak,bohong, iqnya rendah, mempermalukan diri sendiri, otak kosong, tong kosong nyaring bunyinya, banyak ballena, ular berkepala dua, dan seribu wajah. Kedua, Bentuk-bentuk ilokusi fitnah yang dilakukan pengguna sosial media pada masa pra dan pasca pemilihan Walikota Makassar 2020 ditemukan bebarapa bentuk ilokusi tindak tutur ekspresif fitnah yaitu, tidak ada sekali sama sekali kinerja yang diberikan, melakukan korupsi, melakukan kecuangan, calon koruptor, menjadi provokator, melakukan kelicikan, dan mendapatkan bantuan. Ketiga, Bentuk-bentuk ilokusi fitnah dilakukan oleh pengguna media sosial pada masa pra dan pasca pemilihan Walikota Makassar 2020 ditemukan bebarapa bentuk ilokusi tindak tutur ekspresif makian yaitu, telaso, sundala, tidak punya rasa malu, munafik, calon ahli neraka, balao, rakus harta, bau tanah, mulut comberan, kongkong, dan tolotolo.
\end{abstract}

KATA KUNCI: fitnah; kejahatan berbahas;, linguistik forensik; makian; penghinaan.

\section{ANALYSIS OF LANGUAGED CRIMES IN SOCIAL MEDIA (FORENSIC LINGUISTIC)}

\begin{abstract}
This research is a qualitative descriptive study which aims to describe language crimes which have legal impact on expressive illocutionary speech acts in the form of insults, slander, and insults. The data in this study are in the form of words, phrases, clauses, and sentences. Sources of data in this study are social media Facebook, Instagram, Twitter, and Youtube. The data collection techniques in this study were documentation techniques and note taking techniques. The results of this study found that language crimes have legal impact on expressive illocutionary speech acts in the form of insults, slander, and cursing. First, the forms of humiliation illocution that occurred on social media in the pre and post-election period for the 2020 Mayor of Makassar found several forms of illocutionary expressive speech acts of insults, namely nonsense, just talking, using the brain, lying, low IQ, humiliating yourself, empty brain., empty tin barrels sound, many ballena, two-headed snake, and a thousand faces. Second, the forms of illocutionary slander that occurred on social media during the pre and post election for the Mayor of Makassar 2020 found several forms of illocutionary expressive speech acts of slander, namely, there was no performance at all, committed corruption, committed corruption, corrupt candidates. , be a provocateur, practice cunning, and get help. Third, the illocusions of slander that occurred on social media in the pre and post-election period for the 2020 Mayor of Makassar were found in several forms of illocutionary expressive speech acts, namely, telaso, sundala, no shame, hypocrisy, prospective experts in hell, balao, greed for wealth, the smell of the earth, the mouth of sewage, kongkong, and tolo-tolo.
\end{abstract}

KEYWORDS: cursing; forensic linguistics; insults; language crimes; slander.

\begin{tabular}{llll}
\hline Diterima: & Direvisi: & Distujui: & Dipublikasi: \\
2021-07-05 & 2021-07-08 & 2021-09-01 & 2021-10-29
\end{tabular}

Pustaka : Herwin, H., Mahmudah, M., \& Saleh, S. (2021). ANALISIS KEJAHATAN BERBAHASA DALAM BERSOSIAL MEDIA (LINGUISTIK FORENSIK). Fon: Jurnal Pendidikan Bahasa dan Sastra Indonesia, 17(2), 159-168. doi:https://doi.org/10.25134/fon.v17i2.4431 


\section{PENDAHULUAN}

Teknologi informasi berkembang dengan sangat pesat, perkembangan tersebut membuat perubahan pada tatanan sosial di masyarakat, teknologi informasi memiliki banyak manfaat namun juga membawa dampak negatif yakni dapat membawa kemajuan di masyarakat, namun juga menjadi sarana efektif berbagai perbuatan melawan hukum (Subyantoro, 2019; Susanto, 2020). Sebagai contoh, euphoria masyarakat dalam menggunakan sosial media (seperti Facebook, Instagram, Twitter, Youtube, danlain-lain) yang sepertinya telah menjadi rutinitas bagi masyarakat sehingga kontrol diri dan kontrol sosial tidak lagi diperhatikan, hal tersebut berdampak pada konten yang digunakan di dalam bersosial media yang tidak lagi memperhatikan ketentuan hukum atau moral yang berlaku sehingga ada indikasi kejahatan atau tindakan tidak bermoral di dalamnya, hal itulah yang melatarbelakangi peneliti dan juga igin memberikan pencerahan kepada mayarakat agar lebih bijak dalam bersosial media.

Salah satu konten dalam sosial media adalah pemakaian bahasa, sehingga tidak mengherankan jika dengan sangat mudah dijumpai adanya bahasa pada sosial media yang mengarah pada tindak pidana seperti; penghinaan ringan, cacian, hinaan, fitnah, berita bohong, asusila, perjudian, ancaman pembunuhan, atau bentuk intimidasi lainnya terhadap orang lain.Berbagai fakta dapat dijadikan bukti bahwa tindak pidana pada ranah ITE di Indonesia telah sampai pada tataran serius. Misalnya, 1) kasus video penistaan agama pada tahun 2016 oleh Basuki Tjahaja Purnama yang berujung buih selama dua tahun; 2) kasus video pencemaran yang dilakukan oleh selebriti Ahmad Dhani (2019); dan 3) kasus ujaran rasisme dalam sosial media Twitter (2020) yang diperbuat oleh Permadi Arya atau Abu Janda terhadap Natalius Pigai dan masih banyak lagi.

Pada masa Pemilihan Kepala Daerah (Pilkada) di Sulawesi Selatan tahun 2020, khususnya Pemilihan Wali Kota (Pilwalkot) di Kota Makassar yang menampilkan empat pasangan calon, social media misal Instagram, Facebook Twitter, Youtube, dan lain-lainnya menjadi ladang subur bagi warga dunia maya (Netizen) untuk saling serang, menghina, memfitnah, dan memaki dengan bahasa kotor atau bahasa kasar untuk memberikan aspirasi bagi pasangan calon yang didukungnya atau menjatuhkan pasangan calon lainnya yang menjadi antipoda pasangan calon yang didukungnya. Berdasarkan fakta tersebut, ada yang dilaporkan karena kasus penghinaan ringan, menyebarkan berita bohong, hingga defamasi, salah satu data yang menjadi bukti yaitu laporan Paslon Danny Pomanto yang melaporkan anggota kubu Paslon Appi yaitu Erwin Aksa karena dugaan pencemaraan nama baik dan black campaign(Detik.Com, 2020).

Hal tersebut tentulah sangat memilukan, sebab nenek moyang bangsa ini telah mewariskan kepada generasi penerusnya keluhuran budi pekerti berbangsa. Jika hal ini dibiarkan terus terjadi, maka banyangan tentang masa depan bangsa Indonesia akan buruk sudah sangat jelas gambarannya. Oleh sebab itu, hukum harus ditegakkan agar tindakan yang melanggar hukum pada ranah berbahasa dengan teknologi informasi sebagaimana yang dijelaskan dapat ditindas dengan tegas dan tidak terjadi lagi di masyarakat.

Di Indonesia sendiri, peraturan terkait tindakan melanggar hukum melalui teknologi informasi baru ditetapkan pada tanggal 21 April 2008 yaitu UndangUndang Nomor 11 Tahun 2008 tentang Informasi dan Transaksi Elektronik ITE, 
Undang-undang ini merupakan jawaban dari permasalahan kejahatan atau tindak pidana yang berkembang pesat di Indonesia melalui teknologi informasi.

Memahami penggunaan bahasa sebagai tindak pidana bukanlah perkara mudah, dibutuhkan setidaknya dua disiplin ilmu berbeda untuk mengungkapkan fenomena tersebut, yaitu ilmu bahasa (linguistik) dan ilmu forensik (Coulthard et al., 2016). Ilmu bahasa terdiri atas morfologi, fonetik, fonologi, sintaksis, semantik, dan pragmatik. Ilmu bahasa terkait dengan ekspresif manusia dalam berinteraksi sosial adalah pragmatik, yaitu tindak tutur ekspresif. Kebebasan manusia dalam berekspresi menggunakan bahasa sepatutnya memperhatikan kaidah, norma, atau etika yang berlaku dilingkungan dimana bahasa yang digunakan. Oleh sebab itu penting dilakukan pengkajian ilmu linguistik dengan ilmu forensik.

Perpaduan kedua ilmu tersebut kemudian melahirkan disiplin ilmu terapan baru yang disebut linguistik forensik. Ilmu forensik merupakan bidang ilmu pengetahuan yang digunakan sebagai alat bantu untuk menemukan jawaban secara ilmiah, yang kemudian jawaban tersebut dimanfaatkan sebagai bukti-bukti penegakan hukum. Dengan demikian, linguistik forensik sendiri dapat diterjemahkan sebagai kajian ilmiah terhadap bahasa dan pemakaiannya yang diperhadapkan pada upaya penegakan hukum (Olsson \& Luchjenbroers, 2013).

Leonard juga berpendapat bahwa linguistik forensik digunakan untuk memecahkan permasalahn hukum di kasus tertentu dengan melibatkan ilmu linguistik di dalamnya(Leonard, 2006). Saat ini, topik linguistik forensik menjadi sangat popular diperbincangkan, baik oleh kalangan akademisi, praktisi hukum, pemerhati budaya, maupun masyarakat secara umum. Hal ini dikarenakan masalah kejahatan dengan memanfaatkan bahasa sebagai sarananya telah terjadi secara sporadis.

Linguistik forensik pernah dikelompokkan oleh Hugo Warami pada tahun 2018 bahwa komponen kejahatan berbahasa dalam linguistik forensik memuat beberapa elemen forensik yaitu penghinaan, fitnah, bahasa kotor, makian, dan iklan palsu (Warami, 2018), dari kelima elemen forensik tersebut, Hugo Warami mengadaptasi pandangan McMenamin bahwa kelima elemen tersebut dapat ditelaah dengan menggiringnya pada area penelitian linguistik forensic di ranah bahasa dan hukum yaitu semantik dalam interpretasi makna yang mana cakupannya adalah interpretasi kata, frasa, klausa, dan kalimat (interpretation of words, phases, and sentences) (McMenamin, 2002).

Elemen forensik yang dirumuskan Hugo Warami mengadaptasi pandangan McMenamin bahwa elemen tersebut dapat ditelaah dengan menggringnya pada area penelitian linguistik forensik di ranah bahasa dan hukum, tiga dari lima bentuk kejahatan yang dikelompokkan oleh Warami tersebut yakni penghinaan, fitnah, dan makianakan menjadi dasar penelitian ini bertujuan meneliti kasus kejahatan berbahasa di media sosial pada masa pra dan pasca pemilihan walikota Makassar 2020.

Berdasarkan linguistik forensik yang telah dibagi oleh Warami lebih spesifik dan relevan dengan Undang-Undang ITE yang diterapkan di Indonesia, untuk itu mengkaji permasalahan kejahatan berbahasa pada wilayah ke-Indonesiaan lebih tepat menggunakan pembagian tersebut dibandingkan pembagian linguistik forensik banyak dikemukakan oleh para ahli dari luar Indonesia, dengan menggunakan pembagian linguistik Forensik Warami, diharapkan temuan dalam penelitian ini berhasil mengidentifikasi data dan fakta secara jelas dan terstruktur sehingga temuan ini 
dapat dijadikan dasar pijakan pengambilan kebijakan hukum dan sumber edukasi bagi masyarakat. Namun, yang sama pentingnya, penelitian ini diharapkan mampu memperkaya bidang kajian linguistik maupun ilmu pendidikan bahasa.

\section{LANDASAN TEORI}

Linguistik forensik dipakai sebagai aplikasi linguistik yang mendasari sebuah ilmu tertentu untuk praktik ilmu lainnya.Linguistik forensik seperti yang diungkapkan Olsson \& Luchjenbroers (2013) bahwa ranah ilmu ini merupakan ranah interdisipliner antara ilmu bahasa, kejahatan, serta hukum didalamnya termasuk penegakan hukum, bidang yudikatif, aturan-aturan, perselisihan atau proses hukum, bahkan perselisihan yang berpotensi mengindikasi pelanggaran hukum atau kepentingan untuk mencari upaya hukum. Mengingat pusat bahasa untuk kehidupan yang, mengejutkan bahwa linguistik forensik merupakan ilmu interdisipliner yang relatif baru dalam dunia bahasa, hukum, dan kejahatan.

Ciri-ciri umum linguistik forensik memungkinkan bisa disejajarkan ke dalam praktik-praktik linguistik dan analisis kewacanaan lainnya berikut ini: (1) memiliki parameter forensik (hukum dan kriminal) atas linguistik, (2) merupakan pisau bedah yang digunakandalam upaya meretas keterkaitan antara ilmu bahasa, hukum dan kriminal, (3) disebut juga sebagai studi bahasa terhadap teks-teks hukum, (4) membongkar pragmatisme bahasa hukum, (5) mengungkap kejahatan bahasa, dan (6) menjadi pilar rekonsiliasi antarpihak yang betentangan hukum (Warami, 2018).

McMenamin,

mengemukakan bahwa area penelitian linguistik forensik diranah bahasa dan hukum dibedakan menjadi delapan yaitu fonetik auditori, fonetik akustik, semantik dalam interpretasi makna, wacana dan pragmatik, gaya penulisan dan kebebasan bertanya, bahasa hukum, bahasa dalam ruang sidang, serta interpretasi dan terjemahan.Sebegitu pentingnya pemakaian bahasa di dalam kehidupan manusia dan hukum, linguistik forensik merupakan pendatang baru di arena yang sudah lama menjadi permasalahan kemanusiaan, yaitu masalah hukum dan penegakan hukum (Ali \& Heryani, 2012). Seperti sidik jari, shoeprint, jauh lebih tua usianya dan merupakan disiplin yang kehadirannya sudah mapan dalam proses peradilan dengan kata lain, mengapa bahasa yang begitu penting dan menyatu dengan kehadiran manusia telah berkiprah dalam dunia hukum, studi ini mulai berdiri sekitar tahun 1950an-1960an. Jadi, bahasa dan ilmu forensik adalah dua hal yang tidak bias dipisah, sehingga disiplin ilmu linguistik forensik tercipta dengan bemula pada pemakaian bahasa yang diperhadapkan dengan permasalahan hukum, dasar kerja linguistik forensik adalah undang-undang atau hukum yang berlaku dan mengatur tentang pemakaian bahasa.

Warami (2018) menyebutkan bahwa dalam perspektif linguistik forensik, paradigma pembuktian mengandung implikasi pemberian kepastian yang bersifat mutlak bagi setiap orang berdasarkan logika dan pengamatanpengamatan yang diperoleh dari nilai rasa dan pertimbangan akal. Warami mengadaptasi fungsionalitas pembuktian Sir Roland Burrow dalam linguistik forensik (Ali \& Heryani, 2012) bahwa pembuktian dimaksudkan (1) untuk menunjukkan beberapa fakta yang mungkin dikenali sebagai alat/bahan bukti dan (2) beberapa fakta kasus yang mempunyai relevansi dengan peristiwa yang dipersengketakan. Selain itu, Patton (2004) menyebutkan bahwa semua bukti yang ditujukan sebagai alat dalam proses pembuktian terdiri atas tiga bagian, yakni 
(1) data lisan atau testimoni, (2) data tulis (dokumen), dan (3) material.

Berdasar pada pernyataan tersebut, dapat disimpulkan bahwa pengelompokan linguistik forensik oleh Warami adalah pembuktian terhadap data dan fakta kebahasaan sebagaimana delik hukum yang dimaksudkan sebagai kejahatan. Kejahatan berbahasa oleh Warami dibagi dalam lima bentuk yaitu penghinaan, fitnah, makian dengan bahasa kotor dan kasar, iklan palsu, namun di penelitian ini, peneliti konsetrasi pada tiga elemen saja yaitu penghinaan, fitnah, dan makian/bahasa kotor.

\section{Penghinaan}

Penghinaan dalam konteks kejahatan berbahasa di Indonesia masuk dalam ranah tindak pidana penghinaan, atau biasa juga disebut tindak pidana terhadap kehormatan. Tindak pidana terhadap kehormatan atau tindak pidana penghinaan merupakan tindak pidana berupa penyerangan terhadap hak seseorang yang dinilai dapat merusak nama baik, citra baik, atau kehormatan seseorang dihadapan orang lain, kelompok, atau organisasi tertentu (Marpaung, 1997). Dalam Pasal 310 ayat (1) memuat unsur, baik yang bersifat objektif maupun yang bersifat subjektif . Pada kenyataannya memang semua kejahatan yang masuk penghinaan (Bab XVI buku II), maupun penghinaan khusus di luar Bab XVI mengandung sifat yang sama dengan kejahatan pencemaran.

Kejahatan penghinaan dibedakan menjadi panghinaan (Chazawi, 2011). Objek penghinaan memuat berupa citra atau martabat mengenai harga diri dan mengenai nama baik orang pribadi (bersifat pribadi). Sebaliknya penghinaan khusus, objek penghinaan adalah rasa/perasaan harga diri atau martabat mengenai kehormatan dan nama baik yang bersifat komunal atau kelompok.
Dapat disimpulkan bahwa Penghinaan adalah salah satu bentuk kejahatan berbahasa pidana pada kehormatan orang lain dengan bentuk harga diri terhadap hak serta dinilai dapat merusak nama baik, citra baik, atau kehormatan seseorang dihadapan orang lain, kelompok, atau organisasi tertentu dan dapat dikenakan sanksi bagi yang melakukan tidakan tersebut.

\section{Fitnah}

Fitnah dalam KBBI yang artirnya perkataan bohong atau tanpa berrdasarkan kebenaran yang disebarkan dengan maksud menjelekkan orang lain (Redaksi, 2008). Fitnah merupakan komunikasi antar individu dengan orang lain yang memiliki tujuan untuk memberikan anggapan negative atas suatu peristiwa yang dilakukan oleh orang lain dengan fakta palsu yang dapat memengaruhi kehormatan, wibawa, atau nama baik seseorang.

Tindak pidana memfitnah diatur dalam pasal 311 ayat (1) KUHP yang menyatakan bahwa "Jika yang melakukan kejahatan pencemaran atau pencemaran tertulis dibolehkan untuk membuktikanya, dan tuduhan dilakukan bertentangan dengan apa yang diketahui, maka dia diancam melakukan fitnah dengan pidana penjara paling lama empat tahun" (Solahuddin, 2010). Terdapat juga dalam pasal 317 ayat (1) KUHP yang menyatakan bahwa "Barang siapa yang dengan sengaja mengajukan pengaduan atau hoaks kepada penguasa, baik secara tulisan maupun untuk dituliskan, tentang seseorang sehingga kehormatan atau nama baiknya terserang, diancam karena melakukan pengaduan fitnah, dengan pidana penjara paling lama empat tahun (Hamzah, 2011; Mahardika, 2010).

Berdasarkan beberapa pendapat tersebut dapat disimpulkan bahwa fitnah adalah salah satu bentuk kejahatan berbahasa yang berupa perkataan bohong 
atau tanpa berrdasarkan kebenaran yang disebarkan dengan maksud menjelekkan orang lain dan merupakan tindak pidana yang dapat dikenai pasal Undang-Undang.

\section{Makian}

Di dalam buku Tata Bahasa Baku Bahasa Indonesia (Alwi et al., 2019) kata "maki" mempunyai makna sebagai "mengeluarkan kata-kata (ucapan) keji (kotor, kasar dan sebagainya) sebagai bentuk pelampiasan kemarahan atau rasa jengkel". "Memaki" memiliki arti sebagai "mengucapkan kata-kata keji, tidak pantas, kurang adat untuk menyatakan kemarahan atau kejengkelan". "Makian" memiliki arti sebagai "kata keji yang diucapkan karena marah dan sebagainya". Wijana dan Rohmadi menjelaskan bahwa dalam keterkaitan dengan penggunaan kata makian oleh penutur bahasa, mempunyai pandangan bahwa manusia di dalam berkomunikasi, pada umumnya melakukan sebuah interaksi untuk membina kerja sama dengan pihak lain untuk membentuk suatu budaya, mengembangkan kebudayaan tersebut, lalu mewariskannya dalam arti secara luas (Putu \& Muhammad, 2009; Rohmadi \& Putu Wijana, 2013).

Berdasarkan uraian-uraian tersebut, kata makian dapat dilihat dari tanda-tanda sebagai berikut: (1) merupakan ungkapan perasaan tertentu yang munculnya disebabkan oleh dorongan yang bersifat kebahasaan dan nonkebahasaan, (2) merupakan saluran dari emosi dan sikap pembicara, (3) menggunakan kata-kata kasar, tabu, kotor, cabul, keji dan tidak sopan (4) merujuk pada tabu atau stigma dalam suatu lingkungan budaya atau masyarakat, (5) merupakan ungkapan untuk menyinggung harga diri orang lain dan menyakiti hati, (6) sumpah palsu, (7) diucap karena emosi/marah, dan (8) di konteks tertentu bisa digunakan sebagai tanda keintiman dan identitas.

\section{Tindak Tutur Ilokusi Ekspresif}

Berdasarkan fungsi-fungsi tindak tutur yang dikemukakan tersebut, jenis tindak tutur dikaji dalam penelitian ini adalah tindak tutur ilokusi ekspresif karena sejalan dengan bentuk kejahatan berbahasa yakni penghinaan, fitnah dan makian.Menurut Searle (dalam Tarigan, 2015:47) mendeskripsikan tuturan ekspresif adalah bentuk tuturan yang bermanfaat untuk menyatakan atau menunjukkan prilaku psikologis penutur pada keadaan, selanjutnya, Ekspresif adalah salah satu jenis tindak tutur menurut klasifikasi Searle. Ekspresif yakni ujaran atau tindak tutur yang pengungkapan perasaan, sikap, pendapat si penutur. Misalnya berbahasa kotor, mencaci, bahkan memfitnah.

Tindak tutur ekspresif adalah tuturan yang dimaksud pengucapnya agar ujaran/tutran diartikan sebagai penilaian tentang hal yang disebutkan di dalam tuturan itu. Fraser menyebutkan tindak tutur ekspresif dengan istilah evaluatif. Tuturan memuji,mengucapkan terima kasih, mengkritik,mengeluh, menyalahkan, memfitnah, mencaci, dan berbahasa kotor, menyanjung termasuk ke dalam jenis tindak tutur ekspresif.

\section{METODE}

Jenis penelitian yang dipakai yaitu penelitian kualitatif. Penelitian ini memiliki tujuan untuk mendeskripsikan penggunaan kata, frasa dan kalimat di media sosial yang berupa kejahatan berbahasa berdampak hukum terutama pada kasus penghinaan, fitnah, dan makian.Data penelitian ini adalah kata, frasa, klausa, maupun kalimat yang digunakan dalam bersosial media dan mengandung unsur menghina, memfitnah, dan memaki tentang pra dan pasca pemilihan Walikota Makassar. Sumber data penelitian adalah media sosial Facebook, Instagram, Twitter, dan 
Youtube. Konten sosial media dikumpulkan mulai September hingga Desember 2020 berdasarkan Peraturan KPU Nomor 23 Tahun 2018 tentang batasan masa kampanye.

Teknik mengumpulkan data utama dalam penelitian ini adalah teknik dokumentasi dan teknik catat. Teknik dokumentasi meliputi pengumpulan tangkapan layar pada pernyataan warganet di media sosial yang berkaitan dengan kejahatan berbahasa. Teknik catat digunakan untuk mencatat hal-hal yang relevan dari penggunaan bahasa sesuai data yang diinginkan dengan temapenelitian.Teknik analisis data yang digunakan dalam penelitian ini adalah adaptasi teknik analisis data yang dicetuskan oleh Sugiyono (2013) yang meliputi tiga langkah yaitu reduksi data, display atau penyajian data, dan penyimpulan.

\section{HASIL DAN PEMBAHASAN}

Penyajian hasil analisis data didasarkan atas pemahaman peneliti berdasarkan linguistik forensik Warami. Selanjutnya pada bagian ini penulis memaparkan hasil pengamatan dan pembahasan dari analisis kejahatan berbahasa dalam social media berdasarkan linguistik forensik Warami bentuk-bentuk ilokusi penghinaan, bentuk fitnah, dan bentuk makian pada masa pra dan pasca pemilihan Walikota Makassar 2020.

1. Analisis Bentuk-bentuk Ilokusi Penghinaan yang Terjadi di Media Sosial pada Masa Pra dan Pasca Pemilihan Walikota di Kota Makassar Tahun 2020

Hasil analisis data menunjukkan bahwa kejahatan berbahasa bentuk ilokusi penghinaan yang terjadi pada media sosial pada masa pra dan pasca pemilihan Walikota Makassar diasumsikan bermuatan sebagai bentuk kejahatan berbahasa pidana terhadap kehormatan orang lain dengan bentuk penyerangan terhadap hak serta dinilai dapat merusak dinilai dapat merusak nama baik, citra baik, atau kehormatan seseorang dihadapan orang lain, kelompok, atau organisasi tertentu dan dapat dikenakan sanksi bagi yang melakukan tidakan tersebut.

Bentuk-bentuk ilokusi penghinaan yang terjadi di media sosial pada masa pra dan pasca pemilihan Walikota Makassar 2020 ditemukan bebarapa bentuk ilokusi tindak tutur ekspresif penghinaan yaitu omong kosong, omong doang, pakai otak,bohong, iqnya rendah, mempermalukan diri sendiri, otak kosong, tong kosong nyaring bunyinya, banyak ballena, ular berkepala dua, dan seribu wajah. Tindakan tersebut diasumsikan mengandung unsur penggunaan bahasa yang berdampak hukum karena dalam komentar pengguna sosial media tersebut terdapat tindakan penghinaan pada pra dan pasca pemilihan Walikota Makassar 2020. Tuduhan yang dilakukan secara langsung dan dilakukan tanpa adanya paksaan, hal ini terlihat dari setiap unggahan dilakukan pada akun pribadi milik pengguna sosial media tersebut. Bentuk penghinaan merupakan penyerangan terhadap hak serta dinilai dapat merusak nama baik, citra baik, atau kehormatan dihadapan orang lain atau kelompok.

2. Analisis Bentuk-bentuk Ilokusi Fitnah yang Terjadi di Media Sosial pada Masa Pra dan Pasca Pemilihan Walikota di Kota Makassar Tahun 2020

Hasil analisis data menunjukkan bahwa kejahatan berbahasa bentuk ilokusi fitnah yang terjadi di media sosial pra dan pasca pemilihan Walikota Makassar diasumsikan bermuatan sebagai bentuk kejahatan berbahasa Fitnah merupakan salah satu bentuk kejahatan berbahasa yang berupa perkataan bohong atau tanpa berdasarkan kebenaran yang disebarkan dengan maksud menjelekkan orang lain 
dan merupakan tindak pidana yang dapat dijerat dengan pasal Undang-Undang.

Bentuk-bentuk ilokusi fitnah yang terjadi di media sosial pada masa pra dan pasca pemilihan Walikota Makassar 2020 ditemukan bebarapa bentuk ilokusi tindak tutur ekspresif fitnah yaitu, tidak ada sekali sama sekali kinerja yang diberikan, melakukan tindak pidana korupsi, melakukan kecuangan, calon koruptor, menjadi provokator, melakukan kelicikan, dan mendapatkan bantuan.Tindakan tersebut diasumsikan mengandung unsur penggunaan bahasa yang berdampak hukum karena dalam komentar pengguna sosial media tersebut terdapat tindakan fitnah pada pra dan pasca pemilihan calon Walikota Makassar 2020. Tuduhan yang dilakukan oleh pengguna sosial media diperbuat secara langsung dengan menuliskan nama. Kemudian dilakukan tanpa adanya paksaan, hal ini dapat dilihat dari unggahannya yang dilakukan pada akun pribadi milik pengguna sosial media tersebut. Bentuk fitnah yaitu, perkataan bohong atau tanpa dasar kebenaran yang disebarkan dengan maksud menjelekkan seseorang atau kelompok merupakan tindak pidana yang dapat dijerat dengan pasal Undang-Undang.

\section{Analisis Bentuk-bentuk Ilokusi} Makian yang Terjadi di Media Sosial pada Masa Pra dan Pasca Pemilihan Walikota di Kota Makassar Tahun 2020

Hasil analisis data menunjukkan bahwa kejahatan berbahasa bentuk ilokusi makian yang terjadi di media sosial pra dan pasca pemilihan Walikota Makassar diasumsikan bermuatan sebagai bentuk kejahatan berbahasamakian merupakan salah satu bentuk kejahatan berbahasa berupa ungkapan perasaan tertentu yang munculnya disebabkan oleh dorongan yang bersifat kebahasaan dan nonkebahasaan, yang menggunakan katakata tabu, kasar, kotor, cabul, tidak sopan dan keji. Makian merupakan ungkapan untuk menyinggung harga diri orang lain dan menyakiti hati, sumpah serapah, diucapkan karena emosi/marah, dan dalam konteks tertentu dapat digunakan sebagai penanda keintiman dan pernyataan identitas.

Bentuk-bentuk ilokusi fitnah yang terjadi di media sosial pada masa pra dan pasca pemilihan Walikota Makassar 2020 ditemukan bebarapa bentuk ilokusi tindak tutur ekspresif makian yaitu, telaso, sundala, tidak punya rasa malu, munafik, calon ahli neraka, balao, rakus harta, bau tanah, mulut comberan, kongkong, dan tolo-tolo.Tindakan tersebut diasumsikan mengandung unsur penggunaan bahasa yang berdampak hukum karena dalam komentar pengguna sosial media tersebut terdapat tindakan makian pada pra dan pasa pemilihan calon Walikota Makassar 2020. Tuduhan yang dilakukan oleh pengguna sosial media dilakukan secara langsung dan dilakukan tanpa adanya paksaan, hal ini terlihat dari unggahannya yang dilakukan pada akun pribadi milik pengguna sosial media tersebut. Data tersebut merupakan makian yang menggunakan kata-kata tabu, kasar, kotor, cabul, tidak sopan dan keji. Ungkapan tersebut merupakan tindak pidana yang dapat dijerat dengan pasal UndangUndang.

\section{KESIMPULAN}

Ditemukan kejahatan berbahasa berdampak hukum pada tindak tutur ilokusi ekspresif bentuk penghinaan, fitnah, dan makian. Pertama, Bentukbentuk ilokusi penghinaan yang terjadi di media sosial pada masa pra dan pasca pemilihan Walikota Makassar 2020 ditemukan bebarapa bentuk ilokusi tindak tutur ekspresif penghinaan yaitu omong kosong, omong doang, pakai otak,bohong, iqnya rendah, mempermalukan diri sendiri, otak kosong, tong kosong nyaring bunyinya, banyak ballena, ular berkepala 
dua, dan seribu wajah. Kedua, Bentukbentuk ilokusi fitnah yang terjadi di media sosial pada masa pra dan pasca pemilihan Walikota Makassar 2020 ditemukan bebarapa bentuk ilokusi tindak tutur ekspresif fitnah yaitu, tidak ada sekali sama sekali kinerja yang diberikan, melakukan tindak pidana korupsi, melakukan kecuangan, calon koruptor, menjadi provokator, melakukan kelicikan, dan mendapatkan bantuan. Ketiga, Bentuk-bentuk ilokusi fitnah yang terjadi di media sosial pada masa pra dan pasca pemilihan Walikota Makassar 2020 ditemukan bebarapa bentuk ilokusi tindak tutur ekspresif makian yaitu, telaso, sundala, tidak punya rasa malu, munafik, calon ahli neraka, balao, rakus harta, bau tanah, mulut comberan, kongkong, dan tolo-tolo.

\section{DAFTAR PUSTAKA}

Ali, A., \& Heryani, W. (2012). Asas-Asas Hukum Pembuktian Perdata. Jakarta: Kencana.

Alwi, H., Dardjowidjojo, S., Lapoliwa, H., \& Moeliono, A. M. (2019). Tata bahasa baku bahasa Indonesia.

Chazawi, A. (2011). Tindak pidana informasi \& transaksi elektronik: penyerangan terhadap kepentingan hukum pemanfaatan teknologi informasi dan transaksi elektronik: UU no. 11 tahun 2008 Tentang Informasi \& Transaksi Elektronik. Bayumedia Publishing.

Coulthard, M., Johnson, A., \& Wright, D. (2016). An introduction to forensic linguistics: Language in evidence. Routledge.

Detik.Com. (2020). Gelinding Bola Salju Danny Pomanto Vs Erwin Aksa Tak Berhenti di Bawaslu. https://news.detik.com/berita/d5226661/gelinding-bola-salju-dannypomanto-vs-erwin-aksa-tak-berhentidi-bawaslu

Hamzah, A. (2011). Delik-delik tertentu (speciale delicten) dalam KUHP. Penerbit Universitas Trisakti.

Leonard, R. A. (2006). Applying the Scientific Principles of Language Analysis to lssues of the Law. International Journal of the Humanities, 3, 2005.

Mahardika, P. (2010). KUHP (Kitab Undang-Undang Hukum Pidana) dan KUHAP (Kitab Undang-Undang Hukum Acara Pidana). Jakarta: Tim Mahardika.

Marpaung, L. (1997). Tindak pidana terhadap kehormatan: pengertian dan penerapannya: dilengkapi dengan putusan-putusan Mahkamah Agung RI. RajaGrafindo Persada.

McMenamin, G. R. (2002). Forensic linguistics: Advances in forensic stylistics. CRC press.

Olsson, J., \& Luchjenbroers, J. (2013). Forensic linguistics. A\&C Black.

Patton, W. W. (2004). Revictimizing Child Abuse Victims: An Empirical Rebuttal to the Open Juvenile Dependency Court Reform Movement. Suffolk UL Rev., 38, 303.

Putu, W. I. D., \& Muhammad, R. (2009). Analisis Wacana Pragmatik Kajian Teori dan Analisis. Yogyakarta: Yuma Pustaka.

Redaksi, T. (2008). Kamus Bahasa Indonesia. Jakarta: Pusat Bahasa Departemen Pendidikan Nasional, 725.

Rohmadi, M., \& putu Wijana, I. D. (2013). Sosio Linguistik Kajian Teori dan Analisis. Yogyakarta: Pustaka Pelajar.

Solahuddin, K. (2010). Kitab UndangUndang Hukum Pidana dan KUHAP Kitab Undang-undang HUkum Acara Pidana. Jakarta: Visimedia.

Subyantoro, S. (2019). Linguistik Forensik: Sumbangsih Kajian Bahasa dalam Penegakan HUKUM. ADIL Indonesia Journal, 1(1).

Susanto, S. (2020). Potensi Dan 
Tantangan Linguistik Forensik Di Indonesia.

Warami, H. (2018). Integrasi Ilmu Linguistik dalam Wacana Politik Undang-Undang Otonomi Khusus
Papua: Perspektif Studi Morfologi. CaLLs (Journal of Culture, Arts, Literature, and Linguistics), 4(1), $65-76$. 